\title{
Kist Hidatik Ön Tanılı Hasta Serumlarında ELISA ve Western Blotting Yöntemleriyle Ekinokok Antikor Varlığının Araştırılması
}

Investigation of the Echinococcus Antibodies in Sera of Patients with Pre-Diagnosed Hydatid Cyst Using ELISA and Western Blot Methods

${ }^{1}$ Kahramanmaraș Afșin Devlet Hastanesi, Kahramanmaraş, Türkiye

${ }^{2}$ Eskișehir Osmangazi Tip Fakültesi, Tibbi Mikrobiyoloji Anabilim Dalı, Eskișehir, Türkiye

Correspondence:

Nihal DOĞAN

Eskişehir Osmangazi Tıp Fakültesi, Tibbi Mikrobiyoloji Anabilim Dalı, Eskişehir, Türkiye

e-mail: nihaldogan42@gmail.com
${ }^{1}$ Ahsen Çifci, ${ }^{2}$ Nihal Doğan

Kist hidatik(KH) dünyada ve ülkemizde önemli zoonotik enfeksiyonlardan biridir. Bu çalışmada; KH ön tanısı ile girişimsel radyoloji bölümünden perkütan aspirasyonla alınan kist sıvıları Eskişehir Osmangazi Üniversitesi Tip Fakültesi Tibbi Mikrobiyoloji Laboratuvarı’nda direkt mikroskobik inceleme ile değerlendirilmiștir. Değerlendirme sonrası, KH hastalığı ile uyumlu yapıların görüldüğü hastalardan serum örnekleri istenerek, ELISA ve Western Blotting testleriyle Echinococcus granulosus' a karşı antikor varlığı araştırılmıştır. KH hastalığının laboratuvar tanısında ELISA ve Wetern Blotting serolojik tanı yöntemlerinin birbirleriyle ve direkt mikroskobik incelemeyle karşılaştırılması amaçlanmıştır. Girişimsel Radyoloji Polikliniğỉnden gönderilen 16 aspire kist sıvısı direkt mikroskobik inceleme ile değerlendirilmiştir. Bu hastalara ait 16 serum örneği çalışma grubuna alınmış, bu serum örneklerinde ELISA ve Western Blotting yöntemleriyle antikor varlığı araștırılmıștır. Kontrol grubu olarak da kist hidatik ön tanısı ya da şüphesi olmayan, paraziter enfeksiyon bulgusu olmayan, 10 sağlıklı gönüllü serumunda serolojik testlerle E. granulosus’a karşı antikor varlığı araştırılmıştır. 16 serum örneğinin 8'inde ELISA IgG pozitif, 3'ünde şüpheli pozitif, 5'inde negatif bulunmuştur. 16 serumun 14'ünde Western Blotting testi ile pozitif, 2'si negatif sonuçlanmıștır. Direkt mikroskobik incelemenin altın standart olarak değerlendirildiği çalışmamızda ELISA testinin direkt mikroskobik inceleme ile uyumu \%53.3, Western Blotting testinin uyumu \%93.3 oranında bulunmuştur. KH hastalığının serolojik tanısında Western Blotting yönteminin daha güvenilir olduğu ve mümkünse birden fazla serolojik yöntemin kombine edilmesinin tanıya katkı sağlayacağı düşünülmüştür.

Anahtar Kelimeler: Kist hidatik, Echinococcus granulosus, kistik ekinokokkoz,tanı

\section{Abstract}

Hydatid cyst $(\mathrm{CH})$ is one of the important zoonotic infections in the world and in our country. In this study; cyst fluids taken by percutaneous aspiration from the interventional radiology department with a preliminary diagnosis of $\mathrm{CH}$ were evaluated by direct microscopic examination in Eskișehir Osmangazi University Medical Faculty of Microbiology Laboratory. After the evaluation, serum samples were requested from patients with structures compatible with $\mathrm{CH}$ disease, and the presence of antibodies against Echinococcus granulosus was investigated by ELISA and Western Blotting tests. It is aimed to compare ELISA and Western Blotting serological diagnosis methods with each other and with direct microscopic examination in the laboratory diagnosis of $\mathrm{CH}$ disease. 16 aspirated cyst fluids were evaluated by direct microscopic examination which sent from the Interventional Radiology Outpatient Clinic. 16 serum samples taken from the same patients were included in the study group and the presence of antibodies in these serum samples was investigated by ELISA and Western Blotting methods. As a control group, the presence of antibodies against E. granulosus was investigated by serological tests in the sera of 10 healthy volunteers who had no prediagnosis or suspicion of hydatid cyst and no signs of parasitic infection. According to serological test results, ELISA IgG was positive in 8 of 16 serum samples, suspiciously positive in 3, and negative in 5 of them. Of the 16 sera, 14 were positive by Western Blotting and 2 were negative. In our study, in which direct microscopic examination was evaluated as the gold standard, the compatibility of the ELISA test with the direct microscopic examination was found to be 53.3\%, and the Western Blotting test was $93.3 \%$. It was thought that Western Blotting method was more reliable in the serological diagnosis of $\mathrm{CH}$ disease and that combining more than one serological method, if possible, would contribute to the diagnosis.

Keywords: Hydatid cyst, Echinococcus granulosus, cystic echinococcosis, diagnosis

Received 18.01.2022 Accepted 04.03.2022 Online published 08.03.2022 


\section{Giriș}

Kist hidatik (KH) erişkini köpek ve kurt gibi karnivorların ince bağırsağında yaşayan; Echinococcus granulosus başta olmak üzere, Echinococcus türlerinin metasestodunun insan ve diğer arakonaklarda oluşturduğu paraziter bir enfeksiyondur $(1,2)$. Echinococcus türlerinin kesin konakları köpek, kurt, çakal gibi karnivorlar; ara konakları ise insan dahil çeşitli memelilerdir (3). KH, insanda her yaş ve cinsiyette görülmekle birlikte, yaşla insidansın arttığ 1 ve $20-40$ yaş arasında daha sık rastlandığı bilinmektedir. Sosyo-ekonomik düzeyi düşük toplumlarda hastalığın görülme oranı daha yüksektir (4). Dünyanın pek çok yerinde önemli bir halk sağlığı sorununu oluşturan KH, yurdumuzun çeşitli bölgelerinde gerek kasaplık hayvanlarda gerekse insanlarda sıkça rastlanılan ve morbidite ve mortaliteye neden olan önemli paraziter etkenlerin başında gelmektedir.

Tanıda, ultrasonografi (USG), bilgisayarlı tomografi (BT) ve manyetik rezonans (MR) gibi görüntüleme yöntemlerinin yanı sıra; direkt mikroskobik inceleme, serolojik yöntemler, moleküler testler gibi mikrobiyolojik tanı yöntemleri de kullanılmaktadır. Direkt mikroskobik inceleme ile kist sivis1 aspirasyon örneklerinde, kistlerin kendiliğinden yırtılması durumunda safra, balgam, dışkı veya idrarda karakteristik protoskoleks veya çengel yapılarının görülmesiyle doğrudan tanı konabilir. $\mathrm{KH}$ hastalığında serolojik tanı yöntemleri ise esas olarak klinik tanının doğrulanmasında, cerrahi veya antimikrobiyal tedavi sonrasi takip ve prognozun değerlendirilmesinde, seroprevelans çalışmalarında kontrol yöntemlerinin etkinliğinin değerlendirilmesinde kullanılmaktadır. Serolojik tanıda kullanılan çoğu test hasta serumunda spesifik antikorların aranması esasına dayanmaktadır. Spesifik antikorların araştırıldığı yöntemlerde ortaya çıkabilen yalancı negatif ve pozitif sonuçların en aza indirilebilmesi için konfirmasyonu sağlayan yöntemlerle çalışılması gerekli olarak görülmektedir $(5,6,7)$.

Çalışmamızda; girişimsel radyoloji kliniğinden $\mathrm{KH}$ ön tanısıyla gönderilen aspire kist sıvıs1 örneklerinde, direkt mikroskopi ile protoskoleks ve çengel varlığı saptanan hastaların serumlarında Enzyme-Linked ImmunoSorbent Assay (ELISA) ve Western Blotting (WB) yöntemleriyle E. granulosus'a karş1 oluşan antikor varlığının araştırılması planlanmıştır. Bu sonuçların değerlendirilmesi doğrultusunda ELISA ve WB testlerinin sonuçlarının karşılaştırılması ve direkt mikroskobik inceleme sonuçlarıyla uyumunun araştırılması amaçlanmıştır.

\section{Gereç ve Yöntemler}

Eskişehir Osmangazi Üniversitesi Tıp Fakültesi Hastanesi'nde 2016-2019 y1lları arasında klinik ve radyolojik tetkikler sirasında/sonrasında kist hidatik ön tanılı hastalardan Girişimsel Radyoloji Polikliniği'nde perkütan aspirasyon yapılarak Tibbi Mikrobiyoloji Anabilim Dalı Laboratuvarı'na gönderilen 15 aspire kist sıvıs1 ve bu hastalara ait 16 serum örneği çalışma grubuna alınmıştır. Kontrol grubu olarak da kist hidatik ön tanısı ya da şüphesi olmayan, paraziter enfeksiyon bulgusu olmayan, 10 sağlıklı gönüllü serumunda serolojik testlerle antikor varlığ araştırılmıştır. Çalışma öncesi laboratuvarımıza gönderilen tüm kan örnekleri 3000 devir/dakika santrifüj edilerek serumları ayrılmış ve ayrılan serumlar deneylerde kullanılıncaya kadar $-20^{\circ} \mathrm{C}$ 'de saklanmıştır. Çalışmada; direkt mikroskopi, ELISA, Western Blotting tanı yöntemlerinin birbirleri ile performansı karşılaştırılmıştır.

\section{Direkt mikroskobik inceleme}

Girişimsel Radyoloji Polikliniği'nde ultrasonografi eşliğinde alınan ponksiyon materyali 1 ş1k mikroskobunda x10'luk ve x40'llk mikroskobik büyütme ile incelenerek çengel, protoskoleks yapılarının varlığ araştırılmıştır.

\section{ELISA}

Hasta serumlar1, ticari bir ELISA kiti ile (Vircell Microbiologist, Spain, Hydatidosis IgG ELISA) üretici firma prosedürlerine göre çalışılmıştır. Testin prensibi insan serumunda hidatoza karş1 oluşan total IgG antikor 
varlığını araştıran dolaylı immunoenzim testi olup, sonuçlar $450 \mathrm{~nm}$ 'de Bio-Tek cihazı ile okunmuştur. "Cut-off" optik dansitesi, kontrol serumlarına göre çıkarıldıktan sonra, antikor indeksi (AI) hesaplanıp (A $=$ Ïrnek OD/“cutoff" OD x 10) Aİ 11'in üzerinde olan serumlar pozitif, 9'un altında olan serumlar ise negatif olarak değerlendirilmiştir. Aİ 9-11 arasında olan serumlar şüpheli olarak değerlendirilip tekrar çalışmaya alınmıştır.

\section{Western Blotting}

Serumda Echinococcus'a karşı antikor oluşumunu saptayan; Em18, Em95, EgAgB antijenlerini içeren, Anti-Echinococcus Euroline WB (EUROIMMUN Medizinische Labordiagnostika AG, Germany) ticari Western Blot kiti kullanılmıştır. Test prosedürüne göre; kontrol bandı ve $\mathrm{IgG}$ bandında mor renkli boyanma gerçekleşmesi, Echinococcus antijenlerine karşı IgG sınıfi antikorların olduğunu göstermektedir. Test şeritleri tarayıcıda tarandıktan sonra Tablo 1, Tablo 2, Tablo 3 ve Tablo 4'teki kit prosedürlerine göre değerlendirilmiştir.

Tablo 1. Test şeritleri üzerindeki antijenlerin spesifitesi.

\begin{tabular}{lll}
\hline Bant & Antijen & Spesifiklik \\
\hline $\mathbf{2 4 - 2 6}$ kDa & p25/26 & Nonspesifik \\
$\mathbf{2 1}$ kDa & p21 & Ekinokok veya diğer parazitler için spesifik \\
$\mathbf{1 6 - 1 8 ~ k D a ~}$ & p16/18 & Ekinokok için spesifik \\
$\mathbf{7}$ kDa & P7 & Ekinokok için spesifik \\
Em 95 & Em 95 & E.multilocularis için spesifik \\
Em 18 & Em 18 & E.multilocularis için spesifik \\
EgAgB & EgAgB & Ekinokok için spesifik \\
\hline
\end{tabular}

Tablo 2. Kit prosedürüne göre, bantlar üzerindeki antijen kategorileri.

\begin{tabular}{ll}
\hline Kategori & Antijen \\
\hline $\mathbf{1}$ & Antijen: p25/26 \\
$\mathbf{2}$ & Genus-spesifik Echinococcus antijen: EgAgB \\
$\mathbf{3}$ & Echinococcus antijen: p21 \\
$\mathbf{4}$ & Echinococcus antijen: p7 ve p16/18 \\
$\mathbf{5}$ & E.multilocularis antijen: Em18 ve Em95 \\
\hline
\end{tabular}

Tablo 3. Test prosedürüne göre sonuçların değerlendirilmesi

\begin{tabular}{|c|c|}
\hline Sonuç & Yorum \\
\hline Negatif & $\begin{array}{l}\text { Band yok/kategori } 1 \text { 'de } 1 \text { pozitif antijen bandi/kategori } 2 \text { 'de } 1 \\
\text { borderline antijen band1 }\end{array}$ \\
\hline Borderline & $\begin{array}{l}\text { Kategori } 2 \text { 'de pozitif antijen band1/kategori } 3,4 \text { ya da } 5 \text { 'ten en } \\
\text { az birinde } 1 \text { borderline antijen band1 } \\
\text { Taze örnek alınması ve birkaç hafta sonra testin tekrarlanması } \\
\text { önerilir }\end{array}$ \\
\hline Pozitif & $\begin{array}{l}\text { Kategori } 3,4 \text { ya da } 5 \text { 'in en az birinde pozitif antijen band } 1 \\
\text { Kategori 3'ün bir antijen bandı, tek başına veya kategori } 1 \text { 'in bir } \\
\text { antijen bandı ile birlikte pozitif ise, bir Ascaris veya Anisakis } \\
\text { enfeksiyonu nedeniyle çapraz reaktivite meydana gelmiş } \\
\text { olabilir }\end{array}$ \\
\hline
\end{tabular}

Tablo 4. Test prosedürüne göre E. granulosus ve E.mutilocularis ayrımı.

\begin{tabular}{ll}
\hline E. granulosus & $\begin{array}{l}\text { Kategori 2'deki pozitif antijen bandı ve ilaveten kategori } 3 \text { veya 4'ün en az } \\
\text { bir pozitif antijen bandı }\end{array}$ \\
\hline E. multilocularis & $\begin{array}{l}\text { 5. kategorideki en az bir pozitif antijen bandı } \\
\text { Ayrıca diğer kategorilerden de pozitif antijen bandı eşlik edebilir }\end{array}$ \\
\hline
\end{tabular}




\section{Ístatistiksel analiz}

İstatistiksel analizler için Cohen kappa uyum testi kullanılmıştır.

\section{Bulgular}

Çalışma kapsamına Girişimsel Radyoloji Kliniği'nden $\mathrm{KH}$ şüphesiyle gönderilen toplam 16 hastanın serumu ve bu hastalardan perkütan aspirasyonla alınan 15 aspire kist sıvis1 alınd. Bir hasta örneğinde ise radyolojik tetkikler sonrası kistin kalsifiye olduğunun saptanması nedeniyle perkütan aspirasyon ve cerrahi müdahale yapılamadığından bu hastanın aspire kist sıv1s1 değerlendirilemedi. 16 hastadan ve 10 sağlıklı bireyden alınan serum örneklerinde ELISA ve Western Blotting yöntemleriyle anti-Echinococcus IgG antikorları araştırıldı. Hasta grubun kist sıvıları mikroskobik olarak incelendi(Tablo5).

Çalıșma grubunu olușturan 16 hastanın 11'i (\%68.7) erkek, 5'i (\%31.3) kadın, kontrol grubunun ise, 7'si (\%70) erkek, 3'ü (\%30) kadın gönüllülerden oluşmaktaydı. Hastaların yaş aralığ 1 5-79 arasında ve yaş ortalaması 31.75 olarak belirlendi. 15 aspire kist sivisının 15'inde direkt mikroskobik inceleme ile Echinococcus'a ait çengel ve/veya protoskoleks yapıları görüldü. Hasta grubuna ait 16 serum örneğinin 8'inde ELISA IgG pozitif, 3'ünde şüpheli pozitif, 5'inde negatif bulundu. ELISA testinde şüpheli pozitiflik tanımlanan örneklerde test tekrarı yapıldı ve 3 serum örneği aynı şekilde şüpheli pozitif olarak sonuçland. 16 serumun 14'ünde Western Blot testi ile Echinococcus'a karşı spesifik antikor varlığ 1 saptand1, 2 tanesinde antikor tespit edilmedi.

Western Blot ile pozitif sonuç veren 14 örneğin 13'ünde kategori 2 (genus-spesifik Echinococcus antijen: $\mathrm{EgAgB}$ ) antijen band1 saptand1. Bu hastalarda Kategori 2 ye ilave olarak Kategori 3 veya 4'ün en az birinde pozitif antijen bandı eşlik etmekteydi. Buna göre 13 hastanın sonucu E. granulosus olarak yorumland. Kalan 1 örnekte ise Kategori 3 ve 4 'te pozitif bant saptand, fakat $E$. granulosus ve E. multilocularis ayrımı yapılamadı. Bu hastanın akciğerde kisti olduğu ve görüntüleme yöntemleriyle E.multilocularis le uyumlu görüntüleme bulgularının olduğu hasta dosya notlarından öğrenildi. 15 hastanın kistinin karaciğerde, 1'inin akciğerde olduğu radyolojik görüntüleme yöntemleriyle tespit edilmiştir.

Kontrol grubundaki 10 hastaya ait serumun hiçbirinde ELISA ve Western Blot ile seropozitiflik saptanmadi. ELISA ile pozitif ve şüpheli pozitif olarak sonuçlanan örnekler Western Blot ile de pozitif olarak tespit edildi - Western Blot ve ELISA ile negatif sonuç alınan hastalardan 1'inin kist sivisından yapılan direkt mikroskobik incelemede protoskoleks yapıları görüldü. ELISA ile negatif sonuç alınan serumlardan 3 tanesinde Western Blot ile pozitiflik saptandı (Tablo 6).

Tablo 5. Hasta grubunda test sonuçlarının karşılaştırılması

Direkt mikroskopi

ELISA

WB

\begin{tabular}{cccc} 
Pozitif & 15 & 8 & 14 \\
\hline Negatif & 0 & 5 & 2 \\
Şüpheli & 0 & 3 & 0 \\
\hline Toplam & 15 & 16 & 16
\end{tabular}

* ELISA: Enzyme-Linked ImmunoSorbent Assay, WB: Western Blotting 
Tablo 6. Hasta grubunda test sonuçlarının ayrıntılı incelenmesi

\begin{tabular}{cccc}
\hline & Direkt mikroskopi & ELISA & WB \\
\hline 1 & Pozitif & Şüpheli pozitif & Pozitif \\
\hline 2 & Önek yok & Negatif & Pozitif \\
\hline 3 & Pozitif & Pozitif & Pozitif \\
\hline 4 & Pozitif & Şüpheli pozitif & Pozitif \\
\hline 6 & Pozitif & Pozitif & Pozitif \\
7 & Pozitif & Negatif & Pozitif \\
8 & Pozitif & Şüpheli pozitif & Negatif \\
9 & Pozitif & Negatif & Pozitif \\
10 & Pozitif & Pozitif & Pozitif \\
11 & Pozitif & Pozitif & Pozitif \\
12 & Pozitif & Negatif & Pozitif \\
13 & Pozitif & Pozitif & Pozitif \\
14 & Pozitif & Negatif & Pozitif \\
15 & Pozitif & Pozitif & Pozitif \\
\hline 16 & Pozitif & Pozitif & \\
\hline
\end{tabular}

Hastalara ait serum ve aspirasyon materyali örneklerinde, 8 olguda her üç yöntemle de pozitiflik bulundu. Direkt mikroskobisi pozitif bulunan 2 hasta örneğinde ELISA ve Western Blot testiyle negatif sonuç alındı. Western Blot testi ile pozitif olarak değerlendirilen altı serum örneğinde, ELISA testiyle üç örnekte şüpheli pozitiflik, üç örnekte de negatiflik tanımlandı (Tablo 6).

Çalışmamızda Direkt mikroskobik inceleme altın standart olarak değerlendirildi. Buna göre; ELISA testinin direkt mikroskobi ile uyumu \%53.3 olarak belirlendi. WB testinin direkt mikroskobik inceleme yöntemi ile uyumu ise \%93.3 olarak saptandi. ELISA ve WB testlerinin uyumluluk oran $\% 45.1$ olarak belirlendi ( Cohen Kappa $=0.451$ ).

\section{Tartışma ve Sonuç}

KH hastalı̆̆ında şüphenin doğrulanması, genellikle noninvaziv görüntüleme yöntemlerinin kullanımını gerektirmekte; bununla birlikte kistin tümör, apse, basit kist gibi diğer yer kaplayan lezyonlarla ayırıcı tanısının yapilabilmesi ve cerrahi sonras nükslerin daha sağlıklı bir şekilde değerlendirilebilmesi için radyolojik tanının serolojik tanı yöntemleriyle desteklenmesi gerekmektedir $(8,9)$. Ayrica KH'te uygulanan tedavinin takibinde de serolojik test sonuçlarının değerli olması nedeniyle kullanilan bu testlerin duyarlilık ve özgüllüklerinin ve test sonuçlarını etkileyen faktörlerin bilinmesi son derece önem taşımaktadır. Halen KH tanısında standart, yüksek duyarlılık ve özgüllüğe sahip serolojik tanı testi bulunmamaktadır. İmmünolojik tanının duyarlılık ve özgüllüklerinin artırılmasını sağlamak ve en güvenilir sonuçları elde etmek için aynı serumun birden fazla serolojik yöntemle test edilmesi önerilmektedir $(10,11,12)$.

Çalışmamızda serolojik testlerin birbirleriyle karşılaştırılması ve direkt mikroskobik tanı sonuçlarının serolojik test sonuçlarıyla uyumunun araştırılması hedeflenmiştir. Yazar ve ark. tarafından yapılan bir çalışmada kist hidatik şüpheli 221 hastada Indirect Hemagglutination (IHA) ve ELISA yöntemleriyle anti-E. granulosus IgG antikorları araştırılmış ve 153 hasta serumunda (\%69.2) ELISA pozitifliği saptanmıştır. Aynı çalışmada ELISA testi ile cerrahi olarak $\mathrm{KH}$ olduğu doğrulanmış 150 hastanın 145 'inde $(\% 96.7)$ pozitif sonuç alınmıştır (13). Akısü ve ark. (14), cerrahi olarak akciğer $\mathrm{KH}$ tablosu olan 31 hasta ile akciğer KH'i dışında diğer akciğer hastalığ tanısı alan 18 hasta ve 10 sağlıklı insan olmak üzere toplam 59 olguda IHA, ELISA ve WB testlerini kullanmışlardır. Buna göre IHA, ELISA ve WB testlerinin duyarlılığı sirasıyla $\% 96.7, \% 87.1$ ve $\% 100$ olarak bulunurken, bu testlerin özgüllükleri $\% 82.2, \% 89.2$ ve $\% 85.7$ olarak saptanmıştır. Delibaş ve ark. (15), KH şüphesiyle başvuran 465 hastayı ELISA ve IHA yöntemleriyle değerlendirmişler, hastaların \%17'sinde ELISA ile pozitiflik saptamışlardır. KH ön tanısı alan hastalardan 
serolojik doğrulama amaciyla 186 hastadan örnek gönderilen bir başka çalışmada ise ELISA ile \%35.5 oranında anti-Echinococcus IgG seropozitifliği saptanmıştır (16).

Western Blot yöntemiyle duyarlılık, çapraz reaksiyonlar ve E.granulosus - E. multilocularis ayrımını değerlendirmek için yapılan bir çalışmada (17) testin duyarlılığ \%97 olarak saptanmıştır.

Yazar ve ark. (17) Kayseri'de 2242 kişi üzerinde yapmış oldukları seroepidemiyolojik bir çalışmada ise; ELISA ile \%2.72, Western Blot yöntemiyle \%0.94 seropozitiflik saptanmıştır.

Cezayir'de kist hidatik ön tanısıyla opere edilen 78 hastanın kist sivisı direkt mikroskobik inceleme ile değerlendirilerek kist hidatik olduğu doğrulanan bir çalışmada, bu hastalara ait serum örneklerinde WB, ELISA ve IHA testleriyle antikor varllğ 1 araştırılmıştır. Çalışmada 66 hasta serumunda WB, 54 hasta serumunda ise ELISA testi ile çalışılmış ve WB testi ile \%68.1, ELISA testi ile \% 75.9 oranında pozitiflik saptanmıştır (18).

Direkt mikroskobik incelemenin altın standart olarak değerlendirildiği çalışmamızda; 16 serum örneğinin 8'inde ELISA Ig G pozitif, 3'ünde şüpheli pozitif, 5'inde negatif bulunmuştur. ELISA sonuçlarındaki şüpheli pozitif olgular dışlandığında, ELISA testi için duyarlılık \% 53.3 saptanmıştır. Literatürde ELISA testi için değişen oranlarda duyarlılık saptanmasına karşın, KH tanısı doğrulanmış

\section{KAYNAKLAR}

1. Pourseif MM, Moghaddam G, Saeedi N, Barzegari A, Dehghani J,Omidi Y. Current status and future prospective of vaccine development against Echinococcus granulosus Biologicals. $2018: 1-11$.

2. Altaş K, Samastı M. Unat'ın Tip Parazitolojisi. İstanbul Üniversitesi Cerrahpaşa Tıp Fak Vakfı Yayınları. 1995;(15): İstanbul

3. Altıntaş N, Doğanay A. Kistik ekinokokkozis. Doğanay M, Altıntaş (Eds). Zoonozlar:Hayvanlardan insanlara bulaşan enfeksiyonlar. 2009; 901-37.

4. Unat E.K, Yücel A, Atlas K, Samastı M, Unat'ın Tip Parazitolojisi. 5. Bask1, İstanbul: Cerrahpaşa Tıp Fak Vakfi Yayınları.1995;no 15. p. $440-459$ hastalarda yapılan çalışmalara göre, bizim bulduğumuz duyarlılığın düşük olduğu görülmüştür. $\mathrm{Bu}$ durumun kısitlı örnek sayısına ve ticari testin içeriğindeki antijene bağlı olabileceği düşünülmüştür.

Çalışmamızda, Western Blot testi ile hasta serum örneklerinden 14 tanesinde Echinococcus'a karş1 IgG antikor varlığ saptanmıştır. Bir hastaya ait kist sıvısında ise direkt mikroskobik incelemede parazite ait yapılar görülmesine rağmen WB testi ile negatif sonuç alınmıştır. Western Blot testinin direkt mikroskobi ile uyumu \%93.3 olarak belirlenmiştir. Bizim sonuçlarımız literatürdeki WB duyarlılık sonuçlarıyla benzer olup, daha geniş hasta popülasyonunda yapılacak in vitro çalışmalarda daha yüksek duyarlılık sonuçları alınabileceği düşünülmektedir. Buna göre, ELISA testinin kist hidatik tanı veya ön tanılı hastalarda ve hastaların tedavi sonrası takibinde tek başına yeterli olmayacağ tedavinin takibinde daha değerli bir serolojik yöntem olduğu düşünülmüştür. WB testinin doğrulama yöntemi olarak kullanılabileceği görülmüştür.

Sonuç olarak; kist hidatik mikrobiyolojik tanis1 ve tedavi sonrasi takibinde birden fazla serolojik yöntemin beraber uygulanmasının tanı ve takip açısından fayda sağlayacağı, mümkünse bu serolojik yöntemlerden birinin WB olmasının uygun olacağı kanısına varılmıştır. Bununla birlikte, çalışmamız sınırlı sayıda örnek içerdiğinden daha fazla sayıda örnek içeren çalışmalarla desteklenmesi gerekmektedir.

5. https://www.who.int/echinococcosis/resources /jactatropica_200911001/en

6. https://www.cdc.gov/dpdx/dxassistance.html

7. Amr SS, Amr ZS, Jitawi S, Annab H. Hydatidosis in Jordan: an epidemiological study of 360 cases. Ann. Trop. Med. Parasitol. 1994; 88:623-627.

8. Türkiye Zoonotik Hastalıklar Eylem Planı, T.C. Sağlık Bakanlı̆̆g Halk Sağlı̆̆ Genel Müdürlüğ̈̈, 2019; yayın no: 1130, Ankara.

9. Doiz O, Benito R, Sbihi Y, Osuna A, Clavel A, Gómez-Lus R. Western blot applied to the diagnosis and post-treatment monitoring of human hydatidosis. Diagnostic Microbiology and Infectious Disease. 2001;41:139-42. 
10. 1Agudelo-Higuita NI, Brunetti E, McCloskey C. Cystic echinococcosis. J Clin Microbiol, 2016; 54: 518-523.

11. Yılmaz GR, Babür C. Diagnosis of echinococcosis. Turk Hij Den Biyol Derg, 2007; 64: 35-44.

12. Kılıç S, Babur C, Taylan-Ozkan A. Comparison of the results of indirect hemagglutination and ELISA methods for the cases prediagnosed as hydatid cyst disease. Mikrobiyol Bul, 2007; 41: 571-577.

13. Yazar S, Yaman O, Çetinkaya F, Şahin İ. Cystic echinococcosis in Central Anatolia, Turkey. Saudi Med J. 2006; 27: 205-9

14. Akısü C, Bayram Delibaş S, Yuncu G, Aksoy $\mathrm{U}$, Ozkoç S, Biçmen C, et al. Evaluation of IHA, ELISA and Western Blot tests in diagnosis of pulmonary cystic hidatidosis. Tuberk Toraks. 2005; 53: 156-60.

15. Delibaş SB, Ozkoç S, Sahin S, Aksoy U, Akisü C. Evaluation of patients presenting with a suspicion of cystic echinococcosis to the serology laboratory of the Parasitology Department of Dokuz Eylül University Medical Faculty. Turkiye Parazitol Derg. 2006; 30: 279-81.

16. Aydın, Merve, et al. Determination of antiechinococcus IgG antibodies by ELISA in patients with suspected hydatid cyst. Türkiye Parazitoloji Dergisi, 2012; 36.2: 61.

17. Liance M, Janin V, Bresson-Hadni S, Vuitton DA, Houin R, Piarroux R. Immunodiagnosis of Echinococcus infections: confirmatory testing and species differentiation by a new commercial Western Blot. J Clin Microbiol. 2000;38:3718-21

18. 1ait, H., et al. Parasitological study of 78 cases of human cystic echinococcosis collected between 2005 to 2012 in Mustapha hospital center of Algiers. Pathologie-biologie, 2014, 62.6: 369-76. 